\section{a N E W S}

\section{大網地すべりについて}

大網地すべり防止区域は，山形県の北西部東田川郡朝 日村大字大網に所在し，大網は鶴風市（国鉄羽越本線鶴 風駅）より車で約 40 分，県都山形市に至る国道 112 号線 沿いに扇形に分布する山間部落（大網は上村，下村，中 村, 関谷, 七五三掛の 5 部落, 戸数 144 戸，人口約 900 人）である。山伏の倠進霞場で有名な月山（標高 1,980 m）の西斜面にあたり，県下一地すべりの激しい，地す ベり防止区域である。

昭和 43 年度の第22回全国地すべり対策協議会は山形県 において開催されることになっているが，大会時の討議 の主対象地として, 県では本大網地すべり地を選定し た。ここでは地すべり地の一部に氺いて，すでに古くか ら諸調査が奏施され，貴重な調査結果にもとづいて対策 工事も実施されて来た。今回の大会を一層有意義なむの とし，また今後の対策工事を有効にすすめるため，さら に広域にわたって精確な資料を得るべく調查をすすめて いる。ととにその概要を報告する。

1. 地すべり地の概沉当地域は長さ約 $1,500 \mathrm{~m}$, 幅約 $600 \mathrm{~m}$ ，面積 $90 \mathrm{ha}$ におよび，古くから地すべりに よる土地変動が著しく, 不規則な形状を示し各所に小沼 の存在がみられる。また部落の東南に赤川水系梵字川小 支流大網川之，北西方に小網川が流下し，集水区域の平 均こう配は $14^{\circ} \sim 15^{\circ}$ である。当該地域の明治以降にお ける著しい地すべり現象は，明治39４3年と昭和10１3 年に発生:し，特に炤和 $10 \sim 11$ 年の変動は最大水平変位 27 $\mathrm{m}$, 垂直变位 $1.5 \mathrm{~m}$ が記録された。地質は新符三紀中新
世の金山層を基盤とし，乙れを崩積土類が厚く被覆堆積 している。基盤岩の, 頁岩, 砂質凝灰岩, 凝灰質泥岩は 全般的に著しく風化し, 地層の走向は $\mathrm{N} 30^{\circ} \sim 40^{\circ} \mathrm{W}$, 傾 斜 $20^{\circ} \sim 40^{\circ} \mathrm{NE}$ で地表面傾斜之反対の方向を示す。この 基盤を被亚する粘性土類, 集垉岩類は, 尾根状あるいは 台地状の地形を呈し，その厚さむ $6 \sim 50 \mathrm{~m}$, 層相の变化 之と屯に多様で空隙む多く岩質軟弱である。したがって これら岩層の存在は, 地すべり現象の大きな誘因ともな る地下水の挙動を一層複雑化している。

2. 現在までの対策工事について これまで実施さ れた工法は堰堤工事, 集水井工事, 水平ボーリング排水 および表面排水路工事である。堰堤工事は大網川右岸一 帯の崖地の侵蝕による崩壊および河床の低下防止のた め, 昭和 12 年以降 13 基設置された。その後堰堤個所の前 後はおちついた模様であるが，全般的にはまだ不安定な 状沉にある。また集水井工事は, 昭和 37 年度部落中央に 1 基（径 $4.0 \mathrm{~m}$, 深さ $15 \mathrm{~m}$ ) 施行し, 滞水した地下水位 の低下を期待した。次に水平ボーリングによる地下水排 除工事は, 昭和 29 年度より延 590 本部落内㧍よびその周 辺一带に施行した。さらに表面排水路工事は, 全体計画 の約 $20 \%$ にたる約 $5,000 \mathrm{~m}$ を昭和 28 年度以降継続的に 実施した。いずれす今日までそれぞれ設置位置において 効果が得られ，今後も期待し得る状沉にある。

3. 基本的な地すべり防止対策について 上記の対 策に加え，今後全地域の基本的な対策のために，炤和 $41 ・ 42$ 年度にわたって精密な機構調查を实施し, その調 查結果をまって地すべりの原因の除去，防止対策工事を 施行する計画である。今回の調査にあたっては，地すべ り変動地区内についてはあちろんのとと, 変動地区䦥縁 についても適確な資料を得るべく努力している。

(山形県 砂防課)

\title{
編集幹事会の拡充, 改組について
}

\section{山口 真 -}

誌の性格にも影響するようなよほど重要な問題のときに は編集委員会を委員長が主催して開催し問題を決定する という機構を新設しました。委員ので氏名とその尃門お よび職域の分担を列記させて頂きます。

・編集委員長

京 都 大 学 山口 真一 (大学・地球物理)

・編集委員

国 鉄 技 研 山田 剛二 (国鉄・土質力学)

地質調査所安藤武 (通産省・地啠)

農業土木試験場 大平 成人 (農林省・地質鉱物)

新 潟 県 湊元 光春(県・測定計器・防止工事)

横 浜 市 大 中村 三郎 (大学・地学)

林業試 験 場 難波 宣士 (林野庁・林学)

土木研究所渡正亮 (建設省・防止工事)

防災センタ一大石 道夫 (科技庁・砂防)

京都大学 高田 雄次 (編集部)

またての委員会では, シンポジウムの内容の決定とか 学会行事のうちで尃門知識を必要とするものはこてで決 定するととになっております。 